\title{
Isolamento de Arcobacter butzleri de músculos de carcaças de suínos de terminação e de matrizes descartadas abatidos em um matadouro no Estado do Rio Grande do Sul, Brasil
}

\author{
Isolation of Arcobacter butzleri from muscles of the carcasses of fattening pigs and culled sows \\ slaughtered in abattoir in the State of Rio Grande do Sul, Brazil
}

\author{
Sérgio José de Oliveira ${ }^{1,3}$ Nilo Ikuta $^{2}$ Vagner Ricardo Lunge ${ }^{2}$ André Fonseca $^{2}$ Hamilton Luiz Moraes $^{3}$ \\ Beatris Sontaz Kuchenbecker ${ }^{3}$ Daniel Thompson Passos ${ }^{2}$
}

RESUMO

Foram colhidos fragmentos de músculos da carcaça de 74 suínos de abate e de 150 porcas descartadas de granjas de ciclo completo, abatidos em frigorífico no Rio Grande do Sul. Os materiais foram inoculados em meio EMJH (Ellinghausen, MacCullough, Johnson \& Harris), incubados a $30^{\circ} \mathrm{C}$ e o cultivo foi passado a placas de agar sangue através de membrana de 0,45 $4 \mathrm{~m}$. Foram obtidas 69 amostras de Arcobacter sp, classificadas por PCR como A. butzleri, respectivamente de suinos de abate (21 isolamentos, 29,3\%) e matrizes descartadas (48 isolamentos, $32 \%$ ).

Palavras-chave: carcaças, suínos de abate, matrizes descartadas, Arcobacter butzleri.

\section{ABSTRACT}

Portions of muscle from carcasses of 74 fattening pigs and 150 culled sows were collected from abattoir in the State of Rio Grande do Sul, Brazil. The samples were inoculated into EMJH (Ellinghausen, MacCullough, Johnson \& Harris) medium and the culture filtered through $0.45 \mu \mathrm{m}$ membrane on blood agar. Arcobacter sp were isolated, 69 isolates, typed by PCR as Arcobater butzleri, respectively from fattening pigs (21 isolates, $29.3 \%$ ) and culled sows (48 isolates, 32\%).

Key words: carcasses, fattening pigs, culled sows, Arcobacter butzleri.

\section{INTRODUÇÃO}

O gênero Arcobacter compreende determinadas espécies de bactérias anteriormente consideradas como Campylobacter as quais devido às características de aerotolerância e crescimento em baixas temperaturas, distinguem-se dos microorganismos do gênero Campylobacter. As espécies associadas com doença em seres humanos e animais têm sido Arcobacter cryaerophilus, Arcobacter butzleri e Arcobacter skirrowii. O primeiro tem sido isolado de fetos suínos abortados, útero e oviduto de porcas com problemas reprodutivos e do divertículo prepucial de suínos machos (OLIVEIRA et al., 1997; 1999; SCHROEDERTUCKER et al.,1996). A. butzleri tem sido cultivado de casos de enterite em seres humanos (LAUWERS et al., 1996; LERNER et al., 1994), de reservatórios d'agua (JACOB \& FUERPFEIL, 1993) e em maior freqüência de carcaças de frango, pato e de carne suína (ATABAY \& CORRY, 1997; COLLINS et al., 1994; LAMMERDING et al.,1994; OLIVEIRA et al., 2001; RIDSDALE et al., 1998), embora tenha sido também cultivado de líquido prepucial de suínos e de oviduto de porca (OLIVEIRA et al., 1999). A associação de

${ }^{1}$ Médico Veterinário, Doutor Setor de Microbiologia Veterinária, Universidade Luterana do Brasil (ULBRA), Hospital Veterinário, prédio 25. Rua Miguel Tostes, 101, Bairro São Luiz, 92420-280, Canoas-RS. E-mail:serjol@zaz.com.br. Autor para correspondência. ${ }^{2}$ Doutor, Laboratório de Diagnóstico Molecular, ULBRA.

${ }^{3}$ Médico Veterinário MSc, Setor de Microbiologia Veterinária, Hospital Veterinário, ULBRA. 
A. butzleri com casos de enterite humana, o cultivo das bactérias das carcaças de frangos e suínos sugere que sejam patógenos transmitidos através dos alimentos (WESLEY, 1996). Casos de diarréia persistente em seres humanos comprovadamente foram causadas por Arcobacter sp. Assim sendo, a presença das bactérias em carcaças de suínos e aves constitui um risco de infecção ao homem. Foi constatado que $\boldsymbol{A}$. butzleri não é habitante normal do intestino de seres humanos, tendo sido detectado em apenas $2 \%$ de amostras fecais normais examinadas, sendo concluído que, em pacientes com gastroenteríte dos quais se isolam arcobacter, é um forte indício de que os microorganismos tenham sido a causa do problema (MANSFIELD \& FORSITHE, 2000). A primeira constatação da presença de Arcobacter $\boldsymbol{s} p$ em carcaças de suínos ocorreu em Iowa, EUA em 1994, através do isolamento das bactérias de carne suína moída (COLLINS et al., 1994). No Brasil, as bactérias foram cultivadas de órgãos genitais de reprodutores e de fetos suínos abortados (OLIVEIRA et al., 1997; 1999) não tendo sido ainda pesquisada a presença em água e músculos de animais abatidos em frigorífico. O objetivo do presente trabalho foi verificar a presença de Arcobacter $\boldsymbol{s p}$ em carcaças de suínos de abate e em matrizes descartadas de granjas no Rio Grande do Sul.

\section{MATERIAL E MÉTODOS}

Foram colhidos fragmentos do músculo peitoral ascendente das carcaças de 74 suínos sadios em idade de abate e de 150 matrizes descartadas de sete granjas de ciclo completo. As causas de descarte não foram definidas. Os suínos foram abatidos em um frigorífico no Rio Grande do Sul. Os materiais foram colhidos aleatoriamente, 10 a 15 amostras semanais, na linha de abate, após a evisceração das carcaças, sendo inoculados em tubos contendo $10 \mathrm{ml}$ de meio de cultura líquido EMJH (Ellinghausen, MacCullough, Johnson \& Harris) e transportados ao Laboratório de Bacteriologia e Micologia Veterinária, do Hospital Veterinário da ULBRA à temperatura ambiente, no decorrer de duas horas. Os tubos foram, então, incubados a $25-30^{\circ} \mathrm{C}$ por 6 dias. Após este período, foi retirada uma gota do cultivo em EMJH e filtrado através de membrana de ester celulose de $0,45 \mu \mathrm{m}$, depositada diretamente sobre a superfície de meio de cultura agar sangue ovino com base de BHI, em placas (OLIVEIRA et al., 2001). Aproximadamente 0,1ml de cada cultivo foi depositada sobre a membrana filtrante. As placas permaneceram no ambiente durante 50 minutos. Após, foram retiradas as membranas filtrantes, e o inóculo foi distribuído com alça. Arcobacter sp por meio deste procedimento, atravessa a membrana, o que não ocorre com outras bactérias contaminantes. A seguir, as placas foram incubadas em aerobiose a $25-30{ }^{\circ} \mathrm{C}$ por 48 horas. Colônias pequenas, típicas, não hemolíticas foram identificadas e testadas pelo método de Gram, inoculadas em BHI semi-sólido $(0,15 \%$ de agar) e os tubos foram incubados à mesma temperatura por 48 horas. Os cultivos foram examinados em microscópio de campo escuro, objetiva $40 \mathrm{X}$ para a observação de bactérias curvas e espiraladas, extremamente móveis. Foram então realizados testes de oxidase, catalase e verificado o crescimento em agar MacConkey (OLIVEIRA, 2000). Após a identificação fenotípica, foi extraído o DNA de cada amostra de bactéria pelo uso de fenolclorofórmio (SAMBROOK et al., 1989) e realizado o teste de PCR utilizando primers Arco I (5'- AGA AAT TAG CCT GTA TTG TAT C - 3') e Arco II (5' - TAG CAT CCC CGC TTC GAA TGA - 3'), amplificando um fragmento de $1223 \mathrm{bp}$ do gene 16SrRNA e primers Arco II e Butz (5'- CTT GAC ATA GTA AGA ATG ATT TAG - 3'), específico para A. butzleri, amplificando fragmento de 463 bp (HARMON \& WESLEY, 1996; OLIVEIRA et al., 2001). Os produtos da reação por PCR foram visualizados após eletroforese em gel de poliacrilamida e corados com nitrato de prata (SANGUINETTI et al., 1994).

\section{RESULTADOS E DISCUSSÃo}

No presente trabalho, foram examinados suínos abatidos em um único frigorífico. Foram isoladas de músculo de carcaças de suínos 69 amostras de Arcobacter sp classificadas por PCR como $\boldsymbol{A}$. butzleri. As bactérias foram isoladas respectivamente de matrizes descartadas (48 amostras, 32\%) e de suínos de abate (21 amostras, 29,3\%), como consta na tabela 1 . Todas as amostras foram positivas para oxidase e cresceram em meio de MacConkey. As reações para catalase oscilaram entre fracas e negativas. A exemplo de pesquisas realizadas em outros países, Arcobacter sp foram isolados de carcaças de frangos no Brasil, havendo predominância de cultivos positivos para $\boldsymbol{A}$. butzleri (OLIVEIRA et al., 2001). Ainda em relação ao Brasil cabe frisar que as bactérias já foram cultivadas por OLIVEIRA et al. (1997) e OLIVEIRA et al. (1999) de amostras colhidas de fetos e de líquido prepucial de suínos. Por outro lado, na literatura consultada não foi encontrada nenhuma citação sobre o cultivo desses microorganismos a partir de músculos colhidos em carcaças de suínos em matadouros no Brasil ou na 
Tabela 1 - Resultados dos exames laboratoriais em amostras de músculo peitoral ascendente, de carcaças de suínos de abate e de matrizes descartadas, colhidas em um frigorífico localizado no Rio Grande do Sul e o método de isolamento utilizado.

\begin{tabular}{lcccc}
\hline Carcaças & $\mathrm{N}^{\mathrm{o}}$ de Animais & $\begin{array}{c}\mathrm{N}^{\mathrm{o}} \text { de fragmentos de músculo } \\
\text { examinados }\end{array}$ & $\begin{array}{c}\mathrm{N}^{\mathrm{o}} \text { de amostras positivas ao } \\
\text { cultivo de } \text { Arcobacter sp }\end{array}$ & $\begin{array}{c}\boldsymbol{N}^{\boldsymbol{o}} \text { de amostras classificadas } \\
\text { por PCR como } \text { A. } \text { butzleri }\end{array}$ \\
\hline Suínos de abate & 74 & 74 & $21(29,3 \%)$ & 21 \\
Matrizes descartadas & 150 & 150 & $48(32 \%)$ & 48 \\
Total & 224 & 224 & $69(30,8 \%)$ & 69 \\
\hline
\end{tabular}

América do Sul, sendo, portanto, este o primeiro isolamento. A metodologia utilizada no presente trabalho difere da realizada anteriormente por COLLINS et al., (1994) visto que as amostras constituiram-se em fragmentos de músculo das carcaças colhidos diretamente após a evisceração, não tendo sido examinada carne moída. A colheita direta evita a possibilidade de contaminação pelo manuseio posterior no frigorífico, como no caso da carne moída. Resta ainda descobrir de onde se originaram as bactérias presentes nas carcaças. Em Iowa (COLLINS et al., 1994), as amostras para exame foram colhidas de 5 frigoríficos, sendo constatado que, em uma das indústrias, houve 89,2\% de isolamentos de Arcobacter $\boldsymbol{s p}$, enquanto nas demais as taxas de cultivo oscilaram entre $0 \%$ e $13 \%$. Os autores sugeriram que a taxa elevada de contaminação pelas bactérias nas amostras colhidas no primeiro frigorífico teriam sido devidas ao fato de que procediam de granjas com nível de manejo e práticas de higiene deficientes. No entanto, ficou a dúvida se a contaminação poderia ter ocorrido no próprio frigorífico, o que ainda é um campo para pesquisa, considerando-se que os microorganismos também poderiam estar presentes na água utilizada no abate. O cultivo de $\boldsymbol{A}$. butzleri, a partir de fragmentos de músculo de carcaças de reprodutoras suínas descartadas, está sendo aqui registrado pela primeira vez na literatura, visto que, em matrizes, as bactérias até o momento haviam sido isoladas somente dos órgãos genitais e de fetos abortados. Em pesquisas anteriores, realizadas em suínos no Brasil, houve predominância de isolamentos da espécie $\boldsymbol{A}$. cryaerophilus de fetos abortados, útero e ovidutos de porcas e do líquido de divertículo prepucial de reprodutores e de suínos de abate, com poucos cultivos de $\boldsymbol{A}$. butzleri (OLIVEIRA et al., 1997; OLIVEIRA et al., 1999). Esta constatação de que espécies diferentes das bactérias predominaram respectivamente $\boldsymbol{A}$. butzleri em músculo de carcaças e $\boldsymbol{A}$. cryaerophilus em órgãos genitais e fetos de suínos é uma observação que merece estudos epidemiológicos, verificação de diferenças de patogenicidade, diferenças antigênicas e genéticas entre amostras para que seja bem compreendida.

\section{CONCLUSÕES}

Foi constatada a presença de Arcobacter butzleri em amostras de músculo peitoral ascendente, colhidas em carcaças de suínos de abate e de porcas descartadas, abatidas em um frigorífico localizado no Estado do Rio Grande do Sul.

\section{AGRADECIMENTOS}

Os autores agradecem a colaboração dos alunos do Curso de Medicina Veterinária da ULBRA bolsistas de Iniciação Científica, Irineu P. Fock e Letícia Levin e aos Auxiliares de Laboratório Jane M. Brasil e José G. Mancuso.

\section{REFERÊNCIAS BIBLIOGRÁFICAS}

ATABAY, H.I.; CORRY, J.E.L. The prevalence of campylobacters and Arcobacters in broiler chickens. J Applied Microbiol, v.83, p.619-626, 1997.

COLLINS, C.I.; WESLEY I.V.; MURANO, E.A. Incidence of Arcobacter spp in ground porc. Dairy Food Environ Sanit, v.14, p.603, 1994.

HARMON, K.M.; WESLEY, V. Identification of Arcobacter isolates by PCR. Let Appl Microbiol, v.23, p.241-244, 1996

JACOB, J.; LIOR, H.; FUERPFEIL, I. Isolation of Arcobacter butzleri from a drinking water reservoir in eastern Germany. $\mathbf{Z}$ Hyg, v.193, p.557-562, 1993.

LAMMERDING, A. et al. Isolation method for Arcobacter butzleri from poultry. Dairy Food Environmental Sanitation, v.14, p.600, 1994.

LAUWERS, S. et al. Arcobacter butzleri in the elderly in Belgium. In: NEWELL, R. Campylobacters, Helicobacters and related organisms. New York : Plenum, 1996. p.515-517.

LERNER, J.; BRUMBERGER, V.; PREAC-MURSIC, V. Severe diarrhea associated with Arcobacter butzleri. Eur J Clin Microbiol Infect Dis, v.13, p.660-662, 1994.

MANSFIELD, L.P.; FORSITHE, S.J. Arcobacter butzleri, A. skirrowii and A. cryaerophilus - potential emerging human pathogens. Reviews in Medical Microbiology, v.11, p.161-170, 2000 .

OLIVEIRA, S.J. DE et al. Classification of Arcobacter species isolated from aborted pig fetuses and sows with reproductive 
problems in Brazil. Veterinary Microbiology, v.57, p.347-354, 1997.

OLIVEIRA, S.J. DE; WESLEY, I.V.; BAETZ, A.L. Arcobacter cryaerophilus and Arcobacter butzleri isolated from preputial fluid of boars and fattening pigs in Brazil. J Vet Diagn Invest, v.11, p.462-464, 1999.

OLIVEIRA, S.J. DE. Microbiologia veterinária. Guia bacteriológico prático. 2.ed. Canoas : ULBRA, 2000. 240p.

OLIVEIRA, S.J. DE et al. Isolation of Arcobacter spp from poultry carcasses, in Brazil. Ciência Rural, v.31, n.4, p.639-643, 2001.

RIDSDAlE, J.A.; ATABAY, H.I.; CORRY, J.E.L. Prevalence of campylobacters and arcobacters in ducks at the abattoir.
Journal of Applied Microbiology, v.85, p.567-573, 1998.

SAMBROOK, J.; FRITSCH, E.F.; MANIATIS, T. Molecular cloning: a laboratory manual. 2.ed. Spring Harbor : Cold Spring Harbor Laboratory, 1989. 223p.

SANGUINETTI, C.J.; DIAS-NETO, E.; SIMPSON, A.J.G. Rapid silver staining and recovery of PCR products separated on polyacrylamide gels. Biotechniques, v.17, p.915-919, 1994.

SCHROEDER-TUCKER, L. et al. Phenotypic and ribosomal RNA characterization of Arcobacter species isolated from porcine aborted fetuses. J Vet Diagn Invest, v.8, p.86-195, 1996.

WESLEY, I.V. Helicobacter and Arcobacter species: risks for foods and beverages. Journal of Food Protection, v.59, n.10, p.1127-1132, 1996.

Ciência Rural, v. 33, n. 5, set-out, 2003. 